\title{
TPMT*3C Allele
}

National Cancer Institute

\section{Source}

National Cancer Institute. TPMT*3C Allele. NCI Thesaurus. Code C46062.

Human TPMT*3C allele is located in the vicinity of $6 \mathrm{p} 22.3$ and is approximately $26 \mathrm{~kb}$ in length. This allele, a variant form of the TPMT wild-type allele, encodes thiopurine Smethyltransferase protein. TPMT*3C allele exhibits a clinically-relevant SNP (c.874A>G) that results in an $\mathrm{Y} 240 \mathrm{C}$ coding change. This alteration in protein sequence decreases the enzymatic activity of the protein encoded by this allelic variant. 